\title{
Characterization of Waste Frying Oils Obtained from Different Facilities
}

\author{
Huseyin Sanli ${ }^{1,3}$, Mustafa Canakci ${ }^{2,3,}$, Ertan Alptekin ${ }^{2,3}$ \\ ${ }^{1}$ Golcuk Vocational High School, Kocaeli University, 41650 Golcuk, Turkey \\ ${ }^{2}$ Department of Automotive Engineering Technology, Kocaeli University, 41380, Izmit, Turkey \\ ${ }^{3}$ Alternative Fuels R\&D Center, Kocaeli University, 41275, Izmit, Turkey \\ * Corresponding author: Tel: +90 26230322 85, Fax: +90 26230322 03,Email:mustafacanakci@hotmail.com
}

\begin{abstract}
Biodiesel cannot economically compete with petroleum-based diesel fuel because of its high cost problem. This problem may be solved with the use of low cost feedstocks in biodiesel production. Waste frying oils are one of the low cost feedstocks. However, the feedstocks' properties to be processed must be controlled in detail prior to transesterification reaction, since the physical and chemical properties of the feedstock significantly influence biodiesel production reaction as well as fuel properties. Frying oils which are used in various facilities in different conditions (such as frying temperature, time, and kind of food) have significantly different physico-chemical properties. Therefore, in this study, 30 different waste frying oil samples (14 from fish restaurants, 5 from fast-foods, 5 from hospitals, 4 from pastry shops, and 2 from restaurants) were collected and their density, viscosity, total polar material, water content, acid value, iodine value, peroxide value, and heating content were determined and compared to each others. The correlations between the total polar material content (which has to be legally determined to monitor frying oil's degradation level) and density, viscosity, acid value and water content were remarkable. The usage of peroxide value to decide the quality of an oil was misleading.
\end{abstract}

Keywords: Biodiesel, Low cost feedstock, Waste frying oil, Characterization.

\section{Introduction}

One of the most important and critical parameters which are effective in social and economical development of a country is energy. Energy consumption is steadily increasing each passing day as a result of rising world population, technological developments and living standards. At the present day, about $90 \%$ of the world's total energy needs are met by fossil fuels and $45 \%$ of these fossil fuels is petroleum (petroleum's share is supposed to rise to $58 \%$ in 2030) [1, 2]. Although petroleum is the most of energy sources used in the world, its reserves originate from some regions. Thus, the world's many countries such as the USA and European Union (EU) countries have to import their energy requirements. In Table 1, daily petroleum production and consumption amounts of some countries are seen.

Table 1. The petroleum production and consumption amounts of some countries [3]

\begin{tabular}{ccc}
\hline Country & $\begin{array}{c}\text { Petroleum } \\
\text { Consumption } \\
\text { (barrel/day) }\end{array}$ & $\begin{array}{c}\text { Petroleum } \\
\text { Production } \\
\text { (barrel/day) }\end{array}$ \\
\hline USA & 18,690 & 9,056 \\
EU & 13,680 & 2,383 \\
China & 8,200 & 3991 \\
India & 2,980 & 879 \\
Russia & 2,850 & 9,932 \\
Germany & 2,437 & 157 \\
France & 1875 & 71 \\
Turkey & 580 & 53 \\
Greece & 414 & 7 \\
\hline
\end{tabular}

As seen in Table 1, the USA which has the largest industry in the world can produce only the half amount of its petroleum consumption. Situation of EN countries which are poor in terms 
of fossil fuels is worse. These 27 countries can only produce about $17 \%$ of the consumed amount with their own resources. As the result of increased dieselization, diesel fuel (D-2) is the most consumed oil-based engine fuels, and this share is rising progressively each passing year. For example, in Turkey, about 7.4 million tons of D-2 was consumed, while gasoline consumption was only 2 million tons in the year of 2009 [4].

When we consider the pessimistic situation explained above, the importance of alternative diesel fuel which is renewable, sustainable, green (not causing global warming and acid rains) and producible with domestic sources is evidently understood.

Biodiesel which is defined as fatty acid alkyl monoesters derived from feedstocks such as vegetable oils and animal fats is one of the most important renewable energy sources. It has many superior properties over D-2 including renewability, lubricity, biodegrability, exhaust emission etc. Increasing environmental concerns and the need for energy independence have led to the biodiesel market. The global biodiesel market is expected to grow from $\$ 8.6$ billion in 2009 to $\$ 12.6$ billion in 2014 [5]. The EU is the biggest biodiesel producer in the world. As seen in Table 2, annual production of 27 EU countries increased from 3.20 million tons in 2005 to 9.04 million tons in 2009 which means the increase is about 3 times.

Table 2. EU biodiesel production and capacity amounts [6]

\begin{tabular}{ccccc}
\hline Year & $\begin{array}{c}\text { Annual Production } \\
\text { (million tons) }\end{array}$ & $\begin{array}{c}\text { Annual } \\
\text { Growth } \\
(\%)\end{array}$ & $\begin{array}{c}\text { Annual Production Capacity } \\
\text { (million tons) }\end{array}$ & $\begin{array}{c}\text { Annual } \\
\text { Growth } \\
(\%)\end{array}$ \\
\hline 2005 & 3.20 & 65.0 & 4.23 & 88 \\
2006 & 4.90 & 54.0 & 6.07 & 43.50 \\
2007 & 5.74 & 16.8 & 10.29 & 69.55 \\
2008 & 7.70 & 35.7 & 16.00 & 54.49 \\
2009 & 9.04 & 16.6 & 20.91 & 30.69 \\
\hline
\end{tabular}

However, this must be remembered that these figures have been essentially attained through governments' economic stimulations and subsidies which were enforced in accordance with EU directive (2003/30/EC) and this has led to serious tax losses. Biodiesel cannot economically compete with D-2 because of its high cost. As biodiesel is usually obtained from high quality food-grade vegetable oils, the biggest reason of the high cost problem is feedstock cost which approximately accounts for $70-90 \%$ of the total cost of biodiesel production [7, 8]. This problem may be solved with the use of low cost feedstocks in biodiesel production. Waste frying oils are one of these low cost feedstocks. Compared to neat vegetable oils, the cost of waste frying oils is anywhere from $60 \%$ less to free, depending on the source and availability [9]. With this decrease in the feedstock cost, the great difference between the prices of biodiesel and D-2 can be lowered to an acceptable value.

\section{Waste Frying Oils as Biodiesel Feedstock}

In Europe, a total of about 17 million tons vegetable oils are annually consumed and this amount raises approximately $2 \%$ each passing year [10]. It is clearly understood from this figure that there are very big amounts of waste frying oil resources. However, there is no comprehensive study carried out on the waste frying oil potential of the EU countries and very little portion of this waste oil can be collected. When waste frying oils are poured into kitchen sink; they block drains in the course of time, and cause the sewerage not to be used by catching other waste materials in the sewerage system. Thus, they damage waste water 
treatment plants and raise processing costs. According to a study performed in USA, 40\% of the sewerage system blockages are caused by the waste frying oils poured into kitchen sink [10]. Moreover, waste frying oils have eco-toxic properties. If they are spilled onto ground, they will contaminate the soil and so damage plants.

Waste vegetable oils usage in the production of animal feed has been forbidden by European Commission since 2001 because of bovine spongiform encephalopathy (mad cow disease). In addition, these waste oils and fats have not been used in soap production since they may cause health problems. Thus, waste oils and fats can only be used as feedstock in the production of biodiesel. Furthermore, by using waste frying oils as feedstock in biodiesel production, in addition to their positive influence in reducing the final cost of biodiesel, serious environmental pollution problems causing from these waste oils can be eliminated. However, the physical and chemical properties of the feedstock significantly influence biodiesel production reaction as well as fuel properties. Because of this, in order to obtain fuel quality biodiesel, the feedstocks' properties to be processed must be controlled in detail prior to transesterification reaction.

\section{Chemistry of Frying Process}

During frying process, oil is continuously or repeatedly subjected to high temperatures in the presence of air and moisture. Three essential degradation reactions occurs under these conditions are:

- Hydrolysis causing from the moisture content of fried food. This reaction produces free fatty acids (FFA), mono- and diglycerides.

- Oxidation causing from the contact with oxygen. Reaction products are oxidized momomeric, dimeric and oligomeric triglycerides and volatile materials such as aldehydes and ketones.

- Polymerization causing from these two reactions, and high temperatures. This reaction produces dimeric and polymeric triglycerides with ring structure [11-13].

Because of these degradation reactions mentioned above, a number of physical and chemical changes occur in frying oils including increase in viscosity, density, FFA content, total polar material (TPM), polymerized triglycerides, and decrease in smoke point, the number of double bonds, etc. If the frying process is continued, these materials will undergo further degradation and finally the oil will not be appropriate for frying. The frying oil has to be discarded.

Since all degradation products are of polar character, TPM content of frying oil is a good indicator of its degradation level. Thus, in many countries, TPM content of frying oil has been legally accepted as the limit value to decide discard it or not. For example, in Turkey, TPM content of frying oil must not exceed the top level of 25\%. In addition to TPM, as the oil deteriorates, some changes in its physical and chemical properties occur. For instance, during frying, oil's double bonds are ruptured and so its fatty acid composition changes, FFA level and saturation degree increase $[14,15]$. The change in the fatty acid composition influences some oil properties such as iodine value, viscosity, density, heating content. Thus, these properties can also be used to monitor the quality of the frying oil. 


\section{Methodology}

Waste frying oils which are used in different conditions (such as frying temperature, duration, the type and shape of the fryer, kind of food etc.) have significantly different physicochemical properties. In this study, in order to decrease this difference, after classifying the facilities producing waste frying oils into categories, 30 different waste frying oil samples (14 from fish restaurants, 5 from fast-foods, 5 from hospitals, 4 from pastry shops, and 2 from restaurants) were collected and their density, kinematic viscosity, TPM, water content, acid value (AV), iodine value (IV), peroxide value (PV), and heating content were determined and compared to each other. It must be pointed out that, at the end of the project which is carried out with the collaboration of Izmit Municipality, totally, 150 waste frying oil samples will be collected from 7 different sectors and also, in addition to the physico-chemical properties mentioned in this article, saponification value, cetane index and smoke points of all samples will be determined.

The procedures used in the determination of AV, PV, and IV are AOCS Cd 3a-63, AOCS Cd 8-53, and TS EN 14111, respectively.

Samples were coded according to their origins. Namely, FR means waste frying oil sample obtained from fish restaurants, FF means waste frying oil sample from fast-foods, $\mathrm{H}$ means from hospitals, PS means from pastry shops, and R means from restaurants.

\section{Results and discussion}

All results determined are shown in Table 3. When the waste frying oil samples obtained from fast-foods are examined and compared to each other, it is seen that FF1 has the TPM content of $30 \%$ and exceeded the top limit of $25 \%$. Moreover, in addition to TPM, water content, PV and AV of this waste frying oil was the highest. Its AV (17.85 $\mathrm{mg} \mathrm{KOH/g)} \mathrm{was} \mathrm{more} \mathrm{than}$ twice of that of FF5 which was the second highest. FF4's TPM content (24.5\%) was close to the top limit value. In addition, density and viscosity values of this sample were the highest. Its viscosity was $6.95 \mathrm{~mm}^{2} / \mathrm{s}$ higher than that of the second highest viscosity. It was a reasonable result that the peroxides values of FF1 and FF4 which had the highest TPM contents were almost same (50.61 and $50.42 \mathrm{meq} / \mathrm{kg}$ ). However, among the samples obtained from fast-foods, FF4's AV (1.78 mg KOH/g) was the lowest and its IV (95.38 $\mathrm{gI}_{2} / 100 \mathrm{~g}$ ) which is the indicator of unsaturation level was the highest. Whereas its iodine value was expected to be low as the result of destruction of double bonds, the result was not in this expectation. As the heating content increases with saturation, the highest heating content (39741 kJ/kg) belonged to FF5 which was the most saturated sample having an IV of 52.17 $\mathrm{gI}_{2} / 100 \mathrm{~g}$.

Among the samples collected from hospitals, TPM content of H1 (29\%) was the highest and higher than the top limit. Again, the result of the same sample had the highest density, viscosity, water content and lowest iodine value. However, high TPM level which is the indicator of massive deterioration made us think that its peroxide value would be the highest, but it was in the third order among the waste frying oils from hospitals with the value of 20.82 meq $/ \mathrm{kg}$. This may be explained by splitting of hydro peroxides which form during the first stage of the oxidation, in the course of time. AVs of the samples were closer to each other and all of them were lower than $1 \mathrm{mg} \mathrm{KOH} / \mathrm{g}$. 
Table 3. Data obtained from waste frying oil samples*

\begin{tabular}{ccccccccc}
\hline 1 & 2 & 3 & 4 & 5 & 6 & 7 & 8 & 9 \\
\hline FF1 & 0.9237 & 42.28 & 1657.00 & 17.85 & 85.53 & 50.61 & 30.0 & 39223 \\
FF2 & 0.9194 & 39.81 & 1310.30 & 3.74 & 82.29 & 33.78 & 16.0 & 39259 \\
FF3 & 0.9183 & 42.37 & 441.76 & 2.64 & 66.48 & 36.84 & 15.5 & 39090 \\
FF4 & 0.9273 & 51.44 & 1059.30 & 1.78 & 95.38 & 50.42 & 24.5 & 39007 \\
FF5 & 0.9207 & 44.47 & 1181.90 & 8.62 & 52.17 & 19.05 & 19.5 & 39741 \\
H1 & 0.9311 & 47.24 & 1208.7 & 0.52 & 97.30 & 20.82 & 29.0 & 38925 \\
H2 & 0.9231 & 34.80 & 956.78 & 0.93 & 119.81 & 7.75 & 13.5 & 39650 \\
H3 & 0.9273 & 39.91 & 1050.70 & 0.50 & 124.28 & 26.65 & 23.0 & 39322 \\
H4 & 0.9242 & 34.81 & 1021.30 & 0.65 & 126.90 & 10.74 & 15.5 & 39498 \\
H5 & 0.9231 & 35.18 & 785.31 & 0.25 & 121.13 & 28.41 & 14.0 & 39689 \\
PS1 & 0.9238 & 39.89 & 710.03 & 0.56 & 141.26 & 55.92 & 16.0 & 39632 \\
PS2 & 0.9237 & 34.28 & 533.75 & 0.39 & 124.09 & 93.94 & 12.0 & 40336 \\
PS3 & 0.9232 & 32.85 & 568.52 & 0.22 & 126.54 & 74.22 & 16.0 & 39466 \\
PS4 & 0.9223 & 33.79 & 566.53 & 0.17 & 120.86 & 200.38 & 11.5 & 39276 \\
R1 & 0.9219 & 34.34 & 530.05 & 0.37 & 109.19 & 85.17 & 18.0 & 39270 \\
R2 & 0.9216 & 34.64 & 556.44 & 0.63 & 108.26 & 20.69 & 13.0 & 39399 \\
FR1 & 0.9264 & 40.52 & 1200.10 & 5.25 & 112.57 & 43.42 & 20.0 & 39344 \\
FR2 & 0.9269 & 39.86 & 1089.50 & 0.36 & 128.84 & 42.51 & 22.0 & 39404 \\
FR3 & 0.9248 & 36.94 & 753.37 & 0.49 & 122.29 & 49.05 & 16.5 & 39492 \\
FR4 & 0.9252 & 37.12 & 714.90 & 0.41 & 122.99 & 52.05 & 20.0 & 39449 \\
FR5 & 0.9238 & 35.99 & 817.73 & 0.28 & 121.71 & 44.46 & 17.0 & 39519 \\
FR6 & 0.9236 & 35.61 & 966.50 & 0.29 & 127.07 & 46.64 & 16.0 & 39556 \\
FR7 & 0.9241 & 34.89 & 915.33 & 0.75 & 118.83 & 53.77 & 15.5 & 39367 \\
FR8 & 0.9243 & 37.74 & 669.46 & 0.32 & 120.70 & 31.43 & 16.0 & 39518 \\
FR9 & 0.9238 & 35.58 & 1024.10 & 0.34 & 108.58 & 25.39 & 17.0 & 39449 \\
FR10 & 0.9238 & 36.37 & 732.64 & 0.43 & 124.37 & 21.72 & 16.5 & 39652 \\
FR11 & 0.9233 & 33.74 & 670.11 & 0.29 & 120.70 & 39.74 & 17.0 & 39624 \\
FR12 & 0.9239 & 34.85 & 713.93 & 0.41 & 124.48 & 34.24 & 15.5 & 39562 \\
FR13 & 0.9249 & 38.14 & 827.15 & 0.41 & 124.33 & 40.49 & 16.5 & 39465 \\
FR14 & 0.9262 & 41.60 & 1017.80 & 0.48 & 119.72 & 48.31 & 19.5 & 39474
\end{tabular}

*1;Company Code, 2;Density (g/ $\left.\mathrm{cm}^{3} @ 15{ }^{\circ} \mathrm{C}\right), 3 ; \operatorname{Viscosity}\left(\mathrm{mm}^{2} / \mathrm{s} @ 40{ }^{\circ} \mathrm{C}\right), 4$; Water Content (ppm), 5;Acid Value (mgKOH/g), 6;Iodine Value $\left(\mathrm{gI}_{2} / 100 \mathrm{~g}\right)$, 7;Peroxide Value (meq/kg), 8;Total Polar Material (\%), 9; Heating Content $(\mathrm{kJ} / \mathrm{kg})$

Within the waste frying oils from pastry shops, the one which had the highest density, viscosity, water content, AV, and TPM was PS1. However, this sample had the lowest PV (55.92 meq/kg) and the highest IV (141.26 $\left.\mathrm{gI}_{2} / 100 \mathrm{~g}\right)$. Normally, low PV and high IV are attributed to slight oxidative degradation. However, this oil was one of two samples which had the highest TPM content. This situation made us think that the degradation reactions which had increased the TPM content of the oil caused from hydrolysis and polymerization rather than thermal oxidation. High water content and AV can be interpreted as the result of hydrolysis. PS4 which was the first waste frying oil in terms of PV $(106.44 \mathrm{meq} / \mathrm{kg}$ higher than the second one) had the lowest TPM content (11.5\%) and it was amazing.

In this study, 2 samples were collected from restaurants. When we examine the results of these samples, it was seen that their density and viscosity values were almost the same. R1 had higher values than R2 in terms of PV (the difference is $64.48 \mathrm{meq} / \mathrm{kg}$ ) and TPM content (the difference is $5 \%$ ). This showed us that this frying oil was subjected to more degradation 
reaction. However, IVs of these two oils were almost same. Whereas, it was expected that R1 had the lower IV due to higher oxidation reaction leading to splitting of double bonds.

Among the waste frying oil samples obtained from fish restaurants, FR1's AV of $5.25 \mathrm{mg}$ $\mathrm{KOH} / \mathrm{g}$ was 7 times higher than that of second oil. The AVs of other 13 samples were less than $1 \mathrm{mg} \mathrm{KOH/g}$. The density, viscosity, water content and TPM amounts of this oil were within the highest ones.

FR2 which had the highest TPM content (22\%) was within the first three samples in terms of density, viscosity and water content. One of the most remarkable results among waste frying oils obtained from fish restaurants was that all the heating contents were almost the same. The difference between the highest heating value $(39624 \mathrm{~kJ} / \mathrm{kg})$ and the lowest heating value $(39344 \mathrm{~kJ} / \mathrm{kg})$ is only $0.7 \%$.

\section{Conclusions}

According to the results, at first, it must be strongly emphasized that waste frying oils are very heterogeneous feedstock for biodiesel production in terms of physico-chemical properties and must be characterize in detail prior to biodiesel production.

When waste frying oils were compared to each other, it was seen that, in general, fast-food origin waste frying oils' viscosities, water contents and AVs were higher and iodine values were lower than those from other sectors. The most suitable feedstocks were from pastry shops in terms of TPM, AV, and water content. The densities of all the samples were generally close to each other.

The correlation between TPM, density, viscosity, AV, and water content were remarkable. Heating contents of the samples were almost the same. In addition, the measurement of PV as an indicator of oil quality was misleading.

\section{References}

[1] http://www.turksam.org/tr/a1343.html, (accessed on 25.04.2010)

[2] Knecht W, Diesel Engine Development in view of Reduced Emission Standards, Energy 33, 2008, pp.264-271

[3] http://www.cia.gov/library/publications/the-world-factbook/goes/br.html, (accessed on 09.11.2010)

[4] http://www.tupras.com.tr, (accessed on 25.04.2010)

[5] http://www.researchandmarkets.com/research/16d117/global_biodiesel_m, (accessed on 08.03.2010)

[6] http://www.ebb-eu.org/stats.php, (accessed on 07.12.2010)

[7] Predojevic Z, The Production of Biodiesel from Waste Frying Oils: A Comparison of Different Purification Steps, Fuel 17, 2008, pp.3522-3528

[8] Canakci M, Sanli H, Biodiesel Production from Various Feedstocks and Their Effects on the Fuel Properties, Journal of Industrial Microbiology and Biotechnology 35, 2008, pp. 431-441

[9] Canakci M, The Potential of Restaurants Waste Lipids as Biodiesel Feedstocks, Bioresource Techn 98, 2007, 183-190 
[10] Agriculture and Food Development Authority, Waste Oils and Fats as Biodiesel Feedstocks: An Assessment of Their Potential in the EU, ALTENER Program NTBNETT Phase IV, Task 4, Final Report, March 2000

[11] Gertz C. Chemical and Physical Parameters as Quality Indicators of Used Frying Fats, Euro Lipid Science Technology 102, 2000, pp. 566-572

[12] Stevenson SG, Vaisey-Genser M, Eskin NAM, Quality Control in the Use of Deep Frying Oils, JAOCS 61, 1984, pp. 1102-1108

[13]Choe E, Min DB, Chemistry of Deep-Fat Frying Oil, Journal of Food Science 72, 2007, pp. 78-86

[14] Aladedunye FA, Przybylski R, Protecting Oil During Frying: A Comparative Study, Eur J Lipid Sci Tech 111, 2009, pp. 893-901

[15]Knothe G, Steidly KR, A Comparison of Used Cooking Oils: A Very Heterogeneous Feedstock for Biodiesel, Bioresource Technology 100 (23), 2009, pp. 5796-5801 